\title{
Increases in Levels of Procollagenase Messenger RNA in Cultured Fibroblasts Induced by Human Recombinant Interleukin $1 \beta$ or Serum Follow c-jun Expression and Are Dependent on New Protein Synthesis
}

Walter Conca, Pamela B. Kaplan, and Stephen M. Krane

Department of Medicine, Harvard Medical School; and the Medical Services (Arthritis Unit), Massachusetts General Hospital, Boston, Massachusetts 02114

\begin{abstract}
The protein encoded by the protooncogene c-jun, included in the activator protein-1 (AP-1) complex, is probably the critical trans-acting factor controlling transcription of the procollagenase gene which is rate limiting for subsequent synthesis of procollagenase. Therefore, to elucidate possible mechanisms whereby IL-1 stimulates procollagenase synthesis, we measured levels of c-jun and procollagenase mRNA in human serum-starved dermal fibroblasts in response to human recombinant IL-1 $\beta$ (hrIL-1 $\beta$ ). hrIL-1 $\beta$ or serum induced rapid increases in c-jun mRNA levels; mRNA levels declined rapidly after hrIL-1 $\beta$ and more slowly after exposure to serum. The increases in levels of $c-j u n$ mRNA preceded the increases in procollagenase mRNA. Whereas the increases in levels of procollagenase mRNA were blunted by cycloheximide, those of c-jun mRNA were enhanced. We interpret these results as follows: IL-1 or serum induce transcription of c-jun by mechanisms independent of new protein synthesis; c-JUN, the protein product of c-jun in the AP-1 complex, is an essential mediator of the effects of IL-1 or serum in the subsequent induction of expression of the procollagenase gene.
\end{abstract}

\section{Introduction}

Levels of mRNA as well as synthesis and secretion of procollagenase (proC) $)^{1}$ are stimulated by inflammatory cytokines such as IL-1 (1-7) or tumor necrosis factor- $\alpha$ (TNF- $\alpha)(8)$ as well as phorbol esters $(5,6,9,10)$. The mechanism by which proC gene transcription is modulated by phorbol esters in-

This is publication number 1048 of the Robert W. Lovett Memorial Group for the Study of Diseases Causing Deformities.

Address correspondence to Dr. Stephen M. Krane, Arthritis Unit, Massachusetts General Hospital, Boston, MA 02114.

Received for publication 19 December 1988 and in revised form 13 February 1989.

1. Abbreviations used in this paper: AP-1, activator protein- $1 ; \beta_{2}-\mathrm{m}$, $\beta_{2}$-microglobulin; $\mathrm{CHX}$, cycloheximide; hrIL-1 $\beta$, human recombinant IL-1 $\beta$; hrTNF- $\alpha$, human recombinant TNF- $\alpha$; proC, procollagenase; TNF, tumor necrosis factor; TPA, 12-O-tetradecanoyl-phorbol-13-acetate.

J. Clin. Invest.

(c) The American Society for Clinical Investigation, Inc. 0021-9738/89/05/1753/05 \$2.00

Volume 83, May 1989, 1753-1757 volves binding of a nuclear protein to a responsive DNA sequence element, 12-O-tetradecanoyl-phorbol-13-acetate (TPA) responsive element, in the $5^{\prime}$ flanking region of the procollagenase gene (11). A trans-acting factor identified as activator protein-1 (AP-1) binds to this TPA responsive element with high affinity. The protein product of the c-jun protooncogene, c-JUN, is that component of AP-1 that accounts for the DNA binding; binding of c-JUN is enhanced by formation of a complex with the product of the c-fos protooncogene (12-19).

IL-1 has previously been found to increase the levels of the mRNA of the protooncogene c-fos in quiescent human foreskin fibroblasts (20). We therefore conducted experiments to determine if levels of c-jun mRNA are also increased by IL-1. We argued further that if the synthesis of a trans-acting protein(s) is required for expression of the proC gene, then inhibition of protein synthesis should inhibit or diminish transcription of this gene. To test this hypothesis we exposed resting human dermal fibroblasts to human recombinant IL- $1 \beta$ $(\mathrm{hrIL}-1 \beta)$ and analyzed the levels of c-jun and proC mRNA in the presence and absence of cycloheximide (CHX). We also investigated whether serum, which contains factors that stimulate c-jun expression $(21,22)$, would induce proC gene expression. We observed a rapid transient increase in the levels of the mRNA for c-jun after exposure to hrIL- $1 \beta$ and a more prolonged increase after serum. The levels of the mRNA for proC induced by hrIL- $1 \beta$ or serum were blunted by $\mathrm{CHX}$, whereas those for c-jun were augmented.

\section{Methods}

Confluent cultures of human foreskin fibroblasts at passage 6-7 or 13-15 were grown at $37^{\circ} \mathrm{C}$ in humidified $95 \%$ air $/ 5 \% \mathrm{CO}_{2}$ and DME, pH 7.0 (Gibco Laboratories, Grand Island, NY), supplemented with $10 \%$ FCS (Sigma Chemical Co., St. Louis, MO), with changes of medium twice each week. For serum starvation, confluent cultures were maintained in $0.5 \%$ FCS for $48-52 \mathrm{~h}$ before experiments. hrIL- $1 \beta$ and human recombinant TNF- $\alpha$ (hrTNF- $\alpha$ ) were gifts of Biogen (Cambridge, MA); specific activities were $4 \times 10^{7} \mathrm{U} / \mathrm{mg}$ and $9.6 \times 10^{6}$ $\mathrm{U} / \mathrm{mg}$, respectively. CHX was obtained from Aldrich Chemical Co. (Milwaukee, WI). Total cellular RNA was extracted according to Cathala et al. (23). The samples were stored at $-20^{\circ} \mathrm{C}$ before size fractionation in $1 \%$ agarose $/ 3.7 \%$ formaldehyde gels for Northern analysis. rRNA was stained with ethidium bromide and visualized under ultraviolet light. The RNA was transferred (24) to nitrocellulose filters (Schleicher \& Schuell, Inc. Keene, NH). All probes were phenol/chloroform/isoamylalcohol (25:24:1, vol/vol/vol)-purified inserts, obtained after restriction enzyme digestion of the total plasmid, size fractionation, and electroelution. The vector pGEM14, containing the 
open reading frame of $v-j u n$ as an insert of $\sim 1.0 \mathrm{~kb}$, was a gift of Dr. K. Struhl, Harvard Medical School, Boston, MA (25). A subclone of the proC cDNA clone, $\mathrm{K} 4$, containing $\sim 0.6 \mathrm{~kb}$ of the full-length proC cDNA clone, pCllase 1, was a gift of Dr. H. J. Rahmsdorf, Kernforschungszentrum Karlsruhe, Karlsruhe, FRG $(10,11)$. A 0.6-kb human $\beta_{2}$-microglobulin $\left(\beta_{2}-\mathrm{m}\right)$ cDNA probe was provided by Dr. S. GattoniCelli, Harvard Medical School, Boston, MA (26). The probes were labeled with $\left[\alpha-{ }^{32} \mathrm{P}\right]$ deoxyribonucleotidetriphosphates (Amersham Corp., Arlington Heights, IL) by nick translation (27). Prehybridization and hybridization in $50 \%$ formamide were carried out at $42^{\circ} \mathrm{C}$ (28). Final washes were in $0.5 \times$ standard saline citrate (SSC; $1 \times$ SSC $=0.15 \mathrm{M}$ sodium chloride and $0.015 \mathrm{M}$ sodium citrate, $\mathrm{pH} 7.0$ ), $0.1 \%$ SDS at $65^{\circ} \mathrm{C}$. Autoradiography was performed at $-80^{\circ} \mathrm{C}$ using Kodak X-Omat AR films (Eastman Kodak Co., Rochester, NY) and Cronex Hi-Plus intensifying screens (DuPont Instruments, Wilmington, DE).

\section{Results}

Effects of hrIL-1 $\beta$ on levels of c-jun $m R N A$. Addition of $\mathrm{hrIL}-1 \beta(0.1 \mathrm{ng} / \mathrm{ml}$ [Fig. $1 A$ ] or $1.0 \mathrm{ng} / \mathrm{ml}$ [Fig. $1 B])$ to serum-starved human fibroblasts led to a rapid increase in c-jun mRNA levels. Constitutive expression of c-jun was observed in serum-starved fibroblasts after longer exposure of the filter (not shown). The increase in levels of c-jun mRNA after stimulation with hrIL-1 $\beta$ was maximal at $1 \mathrm{~h}$ and then rapidly decreased, returning to baseline between 3 and $6 \mathrm{~h}$. The pattern of the kinetics was similar in cells that were not serum starved (not shown). FCS (10\%) also induced a rapid but small increase ( $20 \%$ that of hrIL- $1 \beta$ at $0.1 \mathrm{ng} / \mathrm{ml} 1 \mathrm{~h}$ after addition) in levels of c-jun mRNA in serum-starved fibroblasts; these levels remained elevated longer than with IL-1 (data not shown). Since class I histocompatibility antigens are expressed on the surface of most somatic cells, we measured levels of the mRNA for $\beta_{2}$-m as a potential standard (Fig. $1 \mathrm{~A}$ ). Although the levels of $\beta_{2}$-m mRNA did not significantly change over the first $3 \mathrm{~h}$ after addition of hrIL- $1 \beta(0.1 \mathrm{ng} / \mathrm{ml})$, they were increased after $6 \mathrm{~h}$ and were still increasing by $24 \mathrm{~h}$. The levels of c-jun mRNA were quantitated as shown in Fig. $1 C$. Since hrIL- $1 \beta$ also affected the levels of $\beta_{2}$-m mRNA, it was possible to use measurements of its abundance as internal reference only for the first $3 \mathrm{~h}$ of incubation. Incubation with $\mathrm{CHX}(10$ $\mu \mathrm{g} / \mathrm{ml}$ ) resulted in augmentation in levels of c-jun mRNA after stimulation with hrIL-1 $\beta$ (Fig. $1 A$, lane 7 ; Fig. $1 B$, lanes $7-9$ ) or FCS $(10 \%$, not shown). This augmentation was also observed in serum-starved cells incubated with $\mathrm{CHX}$ alone, although less pronounced (e.g., ratio of CHX:hrIL-1 $\beta$ plus $\mathrm{CHX}$ at $6 \mathrm{~h}$ was $1: 9.5$ ). In an additional experiment, serum-starved fibroblasts were incubated with hrTNF- $\alpha(30 \mathrm{ng} / \mathrm{ml})$ and the levels of c-jun mRNA determined after $30 \mathrm{~min}$ exposure (Fig. 2). hrTNF- $\alpha$ also induced an increase in c-jun mRNA levels (Fig. 2, lane 3), whereas levels of $\beta_{2}$-m mRNA did not change significantly.

In these experiments, two transcripts of c-jun were observed in the fibroblasts exposed to hrIL- $1 \beta$, hrTNF- $\alpha$, or serum, a major $2.7-\mathrm{kb}$ and a minor 3.4-kb species. These transcripts are consistent with those described previously in HeLa cells (15) and BALB/c 3T3 cells and are accounted for by variations in polyadenylation at the $3^{\prime}$ end of the mRNAs (22). For comparative purposes we also assayed for jun mRNA in a malignant cell line, since neoplastic cells frequently express protooncogenes constitutively. mRNA was detected (Fig. 2, lane 4) in the human colonic tumor cell line, HCT-15 (29). In these cells, the intensity of the 3.4-kb transcript was low, whereas the intensity of the $2.7-\mathrm{kb}$ mRNA species and a mRNA species of $2.0 \mathrm{~kb}$ was similar. The presence of the smaller transcript is probaby accounted for by cross-hybridization of the v-jun probe with the mRNA of the related protooncogene, jun B (30).

Effects of hrIL-1 $\beta$ on levels of proC $m R N A$. After addition of $\mathrm{hrIL}-1 \beta(0.1 \mathrm{ng} / \mathrm{ml}$ [Fig. $3 A$ ] or $1.0 \mathrm{ng} / \mathrm{ml}$ [Fig. $3 B$ ] $)$ to serum-starved fibroblasts, there was a gradual increase in the levels of proC mRNA, clearly detectable by $2 \mathrm{~h}$. The increase was still present at $24 \mathrm{~h}$. Quantitation of the levels of proC

A

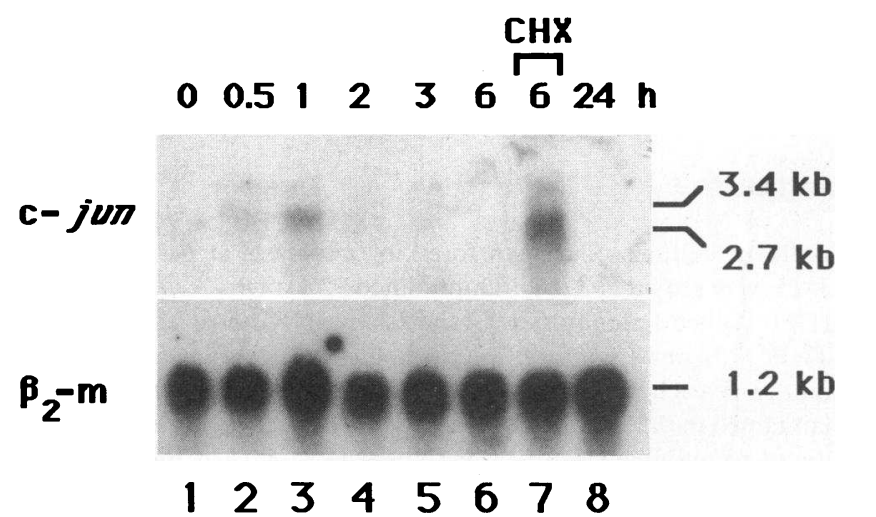

$\mathrm{B}$
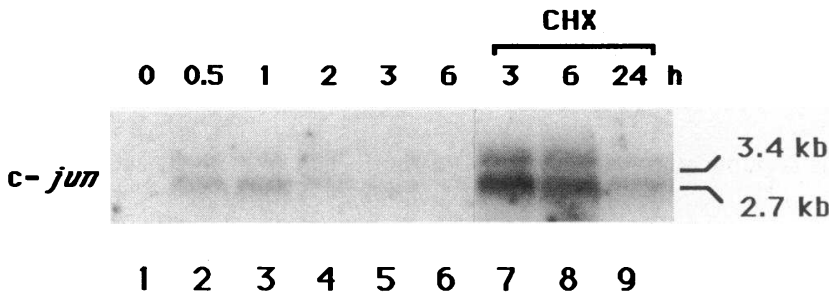

C

Figure 1. Levels of c-jun mRNA in serum-starved fibroblasts. Cells were exposed to $0.1(A)$ or $1.0 \mathrm{ng} / \mathrm{ml}(B)$

C $\quad-$ Jom

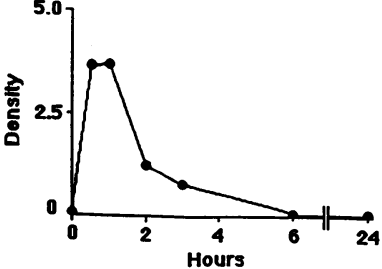
hrIL- $1 \beta$ added at zero time. In $A, 20 \mu \mathrm{g}$ of total cellular RNA was loaded in each lane and in $B, 10 \mu \mathrm{g}$. Films were exposed for $2(A)$ and $8 \mathrm{~d}(B)$. Specific activities of the v-jun probes were $6.8 \times 10^{8}(A)$ and $9.4 \times 10^{7}$ $\mathrm{cpm} / \mu \mathrm{g}(B)$. Addition of CHX $(10 \mu \mathrm{g} / \mathrm{ml})$ is shown in brackets. Quantitation of levels of mRNA of c-jun in fibroblasts exposed to hrIL-1 $\beta(0.1 \mathrm{ng} / \mathrm{ml})$ is shown in $C$. Intensity of bands, determined for different exposures of the autoradiograms, was quantitated with a laser beam densitometer (Biomed Instruments Inc., Fullerton, CA) and normalized for variation in loading of RNA. All values in $A$ and $B$ are expressed in arbitrary density units also correcting for differences in exposure time of films so that values were in the linear range of the densitometer. 


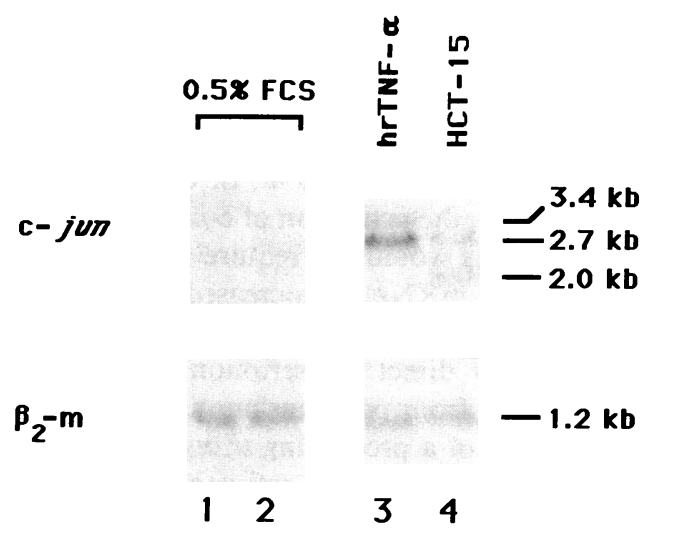

Figure 2. Levels of c-jun mRNA in serum-starved fibroblasts (lanes 1-3) and a human colonic tumor cell line, HCT-15 (lane 4). After 48 $\mathrm{h}$ in $0.5 \%$ FCS (lane 1 ) the fibroblasts were incubated for $0.5 \mathrm{~h}$ with hrTNF- $\alpha(30 \mathrm{ng} / \mathrm{ml}$, lane 3$)$ or $0.5 \%$ FCS (lane 2$) .40 \mu \mathrm{g}$ total cellular RNA was loaded in lanes 1 and $2,20 \mu \mathrm{g}$ in lane 3 , and $20 \mu \mathrm{g}$ poly (A)+ RNA in lane 4. Film was exposed for $1 \mathrm{~d}$. Specific activity of the $v-j u n$ probe was $1.5 \times 10^{9} \mathrm{cpm} / \mu \mathrm{g}$.

mRNA is shown in Fig. $3 C$. CHX $(10 \mu \mathrm{g} / \mathrm{ml})$ significantly decreased the levels of proC mRNA in serum-starved cells exposed to hrIL-1 $\beta$ (Fig. $3 A$, lane 7; Fig. $3 B$, lanes $6-8$ ). In the absence of other stimuli, $\mathrm{CHX}$ did not alter the levels of proC mRNA (not shown). CHX had no effect on levels of $\beta_{2}$-m mRNA after addition of hrIL- $1 \beta$ (Fig. $3 A$, lane 7 ). It should be noted that even at the observed peak of stimulation, the levels of abundance of c-jun mRNA were low compared with those of proC mRNA (Figs. $1 C$ and $3 C$ ).

Effects of serum on levels of proC $m R N A$. After exposure of serum-starved human fibroblasts to serum there was an in- crease in the levels of proC mRNA (Fig. 4). The effect of $20 \%$ FCS on levels of proC mRNA at $6 \mathrm{~h}$ was comparable to that observed with $0.1 \mathrm{ng} / \mathrm{ml}$ of hrIL- $\beta$ (Fig. 4 , lanes 5 and 6 ). $\mathrm{CHX}(10 \mu \mathrm{g} / \mathrm{ml})$ also decreased the levels of proC mRNA in cells exposed to $10 \%$ FCS (Fig. 4, lane 4) consistent with the results obtained with hrIL-1 $\beta$. FCS had no effect on $\beta_{2}-\mathrm{m}$ mRNA levels.

\section{Discussion}

It had previously been shown that the increased levels of collagenase activity in medium from cells exposed to IL-1 could be accounted for by increased synthesis of proC $(2,3)$ associated with marked increases in the levels of proC mRNA (5-7). The analogous stimulation induced by TPA is accounted for by increased transcription of the proC gene as well as increased stability of its mRNA (31). It is likely that the effects of IL-1 and other cytokines such as TNF- $\alpha$ are also explained by transcriptional activation.

Possible candidates for transcriptional regulation of genes such as proC are nuclear oncoproteins. For example, IL- $1 \alpha$, TNF- $\alpha$, and FCS have all been reported to increase the levels of c-fos and c-myc mRNA in human foreskin fibroblasts (20). The synthesis of c-FOS is essential for transcriptional activation of the proC gene induced by TPA (32). In NIH 3T3, HepG2, and HeLa cells, TPA also increases levels of c-jun mRNA as well as c-JUN $(21,33)$. As discussed earlier, AP-1, which includes the proteins c-JUN, c-FOS, and FOS-related antigens, is involved in the activation of proC gene transcription induced by TPA (12-19).

IL-1, TNF- $\alpha$, and serum, all of which induce expression of $c-j u n$ and c-fos in human fibroblasts, could therefore trigger proC gene expression through mechanisms similar to those of TPA. Our observations that increases in the levels of c-jun

A

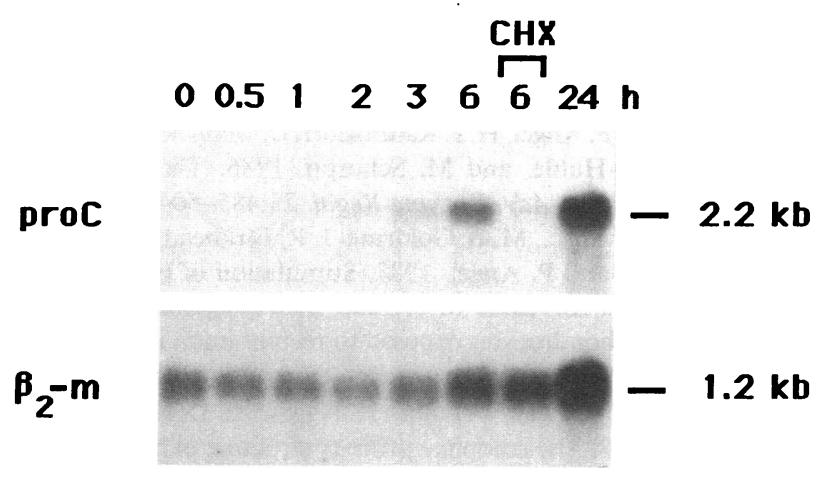

$\begin{array}{llllllll}1 & 2 & 3 & 4 & 5 & 6 & 7 & 8\end{array}$
$\mathrm{B}$

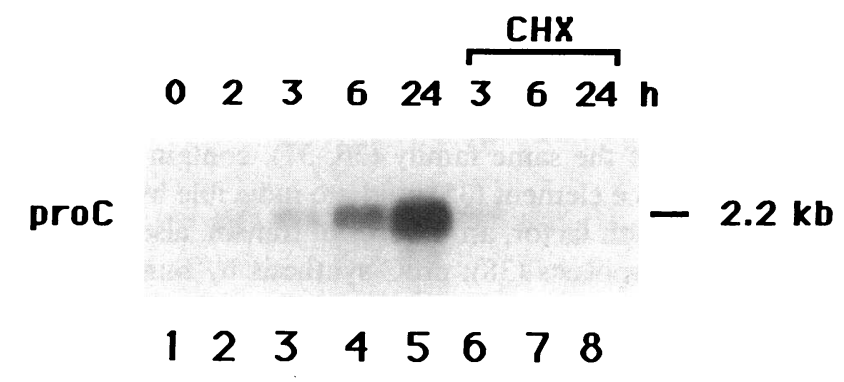

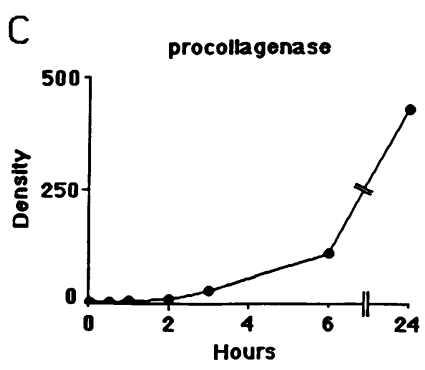

Figure 3. Levels of proC mRNA in serum-starved fibroblasts. Cells were exposed to $0.1(A)$ or $1.0 \mathrm{ng} / \mathrm{ml}$ $(B)$ hrlL-1 $\beta$ added at zero time as in Fig. 1. Addition of $\mathrm{CHX}(10 \mu \mathrm{g} / \mathrm{ml})$ is shown in brackets. Films were exposed for $1(A)$ and $8 \mathrm{~d}(B)$. Specific activity of the proC cDNA probe used in $A$ was $2.4 \times 10^{8} \mathrm{cpm} / \mu \mathrm{g}$ and in $B 1.7 \times 10^{7} \mathrm{cpm} / \mu \mathrm{g}$. $5 \mu \mathrm{g}$ total cellular RNA was loaded in each lane. Quantitation of mRNA of proC in fibroblasts exposed to hrlL-1 $\beta(0.1 \mathrm{ng} / \mathrm{ml})$ is shown in $C$. Arbitrary density units were calculated as in Fig. $1 C$. 


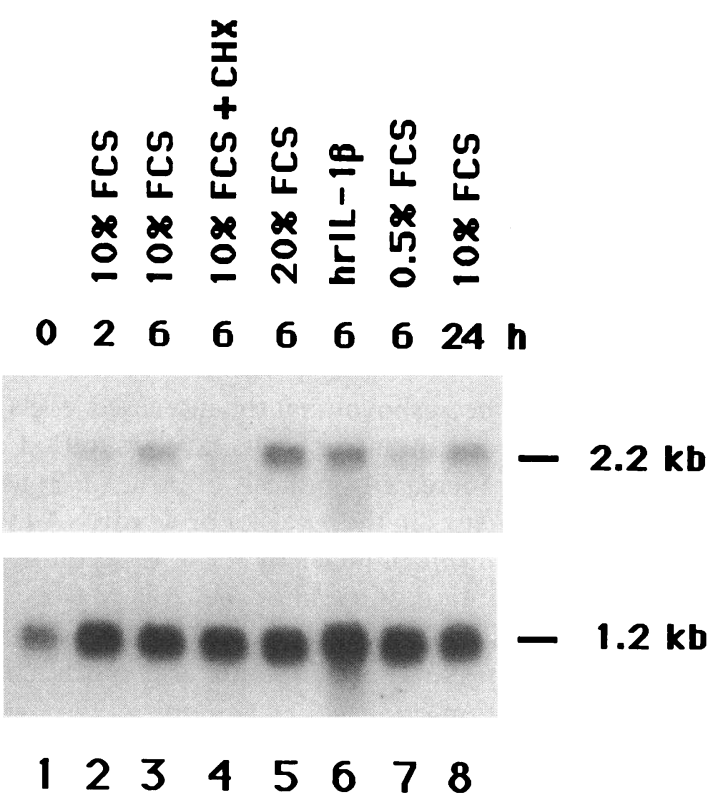

Figure 4. Levels of proC mRNA in serum-starved fibroblasts exposed to 10 (lanes 2, 3, and 8 ) or $20 \%$ FCS (lane 5) added at zero time. For comparison, one of the fibroblast cultures was incubated with hrlL- $1 \beta(0.1 \mathrm{ng} / \mathrm{ml})$ for $6 \mathrm{~h}$ (lane 6$)$. Addition of $\mathrm{CHX}(10 \mu \mathrm{g} / \mathrm{ml})$ is shown in lane 4. Film was exposed for $8 \mathrm{~d}$. $5 \mu \mathrm{g}$ total cellular RNA was loaded in each lane. Specific activity of the proC cDNA probe was $1.7 \times 10^{7} \mathrm{cpm} / \mu \mathrm{g}$.

mRNA precede those of proC mRNA and that inhibition of protein synthesis by $\mathrm{CHX}$ blunts the increases in the levels of proC mRNA induced by IL-1 or serum in serum-starved fibroblasts are consistent with the concept that another transcriptional event that ultimately results in the synthesis of trans-activators such as c-JUN and c-FOS precedes the activation of proC gene transcription by IL-1 or serum under these conditions. CHX also blunts the increases in the levels of proC mRNA after TPA stimulation in human fibroblasts (10). Inhibition of protein synthesis has been shown to block c-JUN synthesis induced by TPA in HeLa cells (33) and abolish the mobility shift seen after TPA stimulation of NIH 3T3 cells assayed using nuclear extracts and binding to an oligonucleotide with the AP-1 binding consensus sequence (34). The transcriptional regulation of the prostromelysin (transin) gene in rats is similar to that of the human proC gene (35). Both genes are members of the same family $(36,37)$, contain the AP-1 binding sequence element (35), and are inducible by IL-1 (7). Epidermal growth factor, an inducer of transin, also activates c-jun in rat fibroblasts (38); proC synthesis by human fibroblasts stimulated with epidermal growth factor is also blocked by actinomycin D or CHX (39). The increases in the levels of $\beta_{2}$-m mRNA, which we observed only after $6-24 \mathrm{~h}$ exposure of the fibroblasts to hrIL-1 $\beta$, were unexpected. In endothelial cells, surface expression of the heavy chains of the class I histocompatibility antigens is not altered by IL-1 (40) although surface expression and levels of their mRNAs are increased by TNF- $\alpha(41)$. In the present study, in contrast to proC mRNA, the levels of $\beta_{2}$-m mRNA enhanced by IL- 1 were not decreased by the addition of $\mathrm{CHX}$; the presumptive increase in $\beta_{2}-\mathrm{m}$ gene transcription induced by IL-1 therefore probably is not dependent on new AP-1 synthesis.
In conclusion, our data are consistent with the concept that at least under conditions of serum starvation, transcription of c-jun and new synthesis of the trans-acting protein c-JUN are involved in the mechanism of transcriptional activation of the proC gene by factors such as IL- $1 \beta$, TNF- $\alpha$, or components present in serum. In contrast, the activation of c-jun transcription induced by these ligands would not require new protein synthesis since levels of c-jun mRNA are increased rather than decreased by $\mathrm{CHX}$. These increases in levels of c-jun mRNA, therefore, result from either direct transcriptional effects of these ligands or more likely from posttranslational modification (e.g., phosphorylation) of a preexisting trans-acting protein(s). Since c-JUN can function as an activator of its own gene (33), IL-1 could effect initiation of transcription of c-jun through the formation of a heteropolymer of preexisting c-JUN, c-FOS, and FOS-related antigens.

\section{Acknowledgments}

We thank Drs. P. E. Auron, S. Gattoni-Celli, M. B. Goldring, and M. L. Stephenson for advice, discussion, and critical review of the manuscript, and $M$. Angelo for preparation of the manuscript.

This work was supported by U. S. Public Health Service grants AM-03564 and AM-07258. W. Conca is supported by a postdoctoral fellowship from the Deutscher Akademischer Austauschdienst.

\section{References}

1. Dayer, J.-M., M. L. Stephenson, E. Schmidt, W. Karge, and S. M. Krane. 1981. Purification of a factor from human blood monocyte-macrophages which stimulates the production of collagenase and prostaglandin $E_{2}$ by cells cultured from rheumatoid synovial tissues. FEBS (Fed. Eur. Biochem. Soc.) Lett. 124:253-256.

2. Postlethwaite, A. E., L. B. Lachman, C. L. Mainardi, and A. H. Kang. 1983. Interleukin 1 stimulation of collagenase production by cultured fibroblasts. J. Exp. Med. 157:801-806.

3. McCroskery, P. A., S. Arai, E. P. Amento, and S. M. Krane. 1985. Stimulation of procollagenase synthesis in human rheumatoid synovial fibroblasts by mononuclear cell factor/interleukin 1. FEBS (Fed. Eur. Biochem. Soc.) Lett. 191:7-12.

4. Dayer, J.-M., B. de Rochemonteix, B. Burrus, S. Demczuk, and C. A. Dinarello. 1986. Human recombinant interleukin 1 stimulates collagenase and prostaglandin $\mathrm{E}_{2}$ production by human synovial cells. J. Clin. Invest. 77:645-648.

5. Herrlich, P., P. Angel, H. J. Rahmsdorf, U. Mallick, A. Pöting, L. Hieber, C. Lücke-Huhle, and M. Schorpp. 1986. The mammalian genetic stress response. Adv. Enzyme Regul. 25:485-504.

6. Stephenson, M. L., M. B. Goldring, J. R. Birkhead, S. M. Krane, H. J. Rahmsdorf, and P. Angel. 1987. Stimulation of procollagenase synthesis parallels increases in cellular procollagenase mRNA in human articular chondrocytes exposed to recombinant interleukin $1 \beta$ or phorbol ester. Biochem. Biophys. Res. Commun. 144:583-590.

7. Saus, J., S. Quinones, Y. Otani, H. Nagase, E. D. Harris, Jr., and M. Kurkinen. 1988. The complete primary structure of human matrix metalloproteinase-3: identity with stromelysin. J. Biol. Chem. 263:6742-6745.

8. Dayer, J.-M., B. Beutler, and A. Cerami. 1985. Cachectin/tumor necrosis factor stimulates collagenase and prostaglandin $E_{2}$ production by human synovial cells and dermal fibroblasts. J. Exp. Med. 162:2163-2168.

9. Brinckerhoff, C. E., R. M. McMillan, J. V. Fahey, and E. D. Harris, Jr. 1979. Collagenase production by synovial fibroblasts treated with phorbol myristate acetate. Arthritis Rheum. 22:1109-1116.

10. Angel, P., A. Pöting, U. Mallick, H. J. Rahmsdorf, M. Schorpp, and $P$. Herrlich. 1986. Induction of metallothionein and other mRNA species by carcinogens and tumor promoters in primary human skin fibroblasts. Mol. Cell. Biol. 6:1760-1766. 
11. Angel, P., I. Baumann, B. Stein, H. Delius, H. J. Rahmsdorf, and P. Herrlich. 1987. 12-O-tetradecanoyl-phorbol-13-acetate induction of the human collagenase gene is mediated by an inducible enhancer element located in the 5'-flanking region. Mol. Cell. Biol. 7:2256-2266.

12. Angel, P., M. Imagawa, R. Chiu, B. Stein, R. J. Imbra, H. J. Rahmsdorf, C. Jonat, P. Herrlich, and M. Karin. 1987. Phorbol esterinducible genes contain a common cis element recognized by a TPAmodulated trans-acting factor. Cell. 49:729-739.

13. Lee, W., P. Mitchell, and R. Tjian. 1987. Purified transcription factor AP-1 interacts with TPA-inducible enhancer elements. Cell. 49:741-752.

14. Bohmann, D., T. J. Bos, A. Admon, T. Nishimura, P. K. Vogt, and R. Tjian. 1987. Human proto-oncogene c-jun encodes a DNA binding protein with structural and functional properties of transcription factor AP-1. Science (Wash. DC). 238:1386-1392.

15. Angel, P., E. A. Allegretto, S. T. Okino, K. Hattori, W. J. Boyle, T. Hunter, and M. Karin. 1988. Oncogene jun encodes a sequence-specific trans-activator similar to AP-1. Nature (Lond.). 332:166-171.

16. Rauscher, F. J., III, D. R. Cohen, T. Curran, T. J. Bos, P. K. Vogt, D. Bohmann, R. Tjian, and B. R. Franza, Jr. 1988. Fos-associated protein $\mathrm{p} 39$ is the product of the jun proto-oncogene. Science (Wash. DC). 240:1010-1016.

17. Chiu, R., W. J. Boyle, J. Meek, T. Smeal, T. Hunter, and M. Karin. 1988. The c-Fos protein interacts with c-Jun/AP-1 to stimulate transcription of AP-1 responsive genes. Cell. 54:541-552.

18. Sassone-Corsi, P., W. W. Lamph, M. Kamps, and I. M. Verma. 1988. fos-Associated cellular p39 is related to nuclear transcription factor AP-1. Cell. 54:553-560.

19. Curran, T., and B. R. Franza, Jr. 1988. Fos and Jun: the AP-1 connection. Cell. 55:395-397.

20. Lin, J.-X., and J. Vilček. 1987. Tumor necrosis factor and interleukin-1 cause a rapid and transient stimulation of c-fos and c-myc mRNA levels in human fibroblasts. J. Biol. Chem. 262:1190811911.

21. Lamph, W. W., P. Wamsley, P. Sassone-Corsi, and I. M. Verma. 1988. Induction of proto-oncogene JUN/AP-1 by serum and TPA. Nature (Lond.). 334:629-631.

22. Ryder, K.,and D. Nathans. 1988. Induction of protooncogene c-jun by serum growth factors. Proc. Natl. Acad. Sci. USA. 85:84648467.

23. Cathala, G., J.-F. Savouret, B. Mendez, B. L. West, M. Karin, J. A. Martial, and J. D. Baxter. 1983. A method for isolation of intact, translationally active ribonucleic acid. $D N A(N Y)$. 2:329-335.

24. Thomas, P. S. 1980. Hybridization of denatured RNA and small DNA fragments transferred to nitrocellulose. Proc. Natl. Acad. Sci. USA. 77:5201-5205.

25. Maki, Y., T. J. Bos, C. Davis, M. Starbuck, and P. K. Vogt. 1987. Avian sarcoma virus 17 carries the jun oncogene. Proc. Natl. Acad. Sci. USA. 84:2848-2852.

26. Suggs, S. V., R. B. Wallace, T. Hirose, E. H. Kawashima, and K. Itakura. 1981. Use of synthetic oligonucleotides as hybridization probes: isolation of cloned cDNA sequences for human $\beta_{2}$-microglobulin. Proc. Natl. Acad. Sci. USA. 78:6613-6617.
27. Rigby, P. W. J., M. Dieckmann, C. Rhodes, and P. Berg. 1977. Labeling deoxyribonucleic acid to high specific activity in vitro by nick translation with DNA polymerase I. J. Mol. Biol. 113:237-251.

28. Anderson, M. L. M., and B. D. Young. 1985. Quantitative filter hybridisation. In Nucleic Acid Hybridisation: A Practical Approach. B. D. Hames and S. J. Higgins, editors. IRL Press, Oxford-Washington, DC. 73-111.

29. Dexter, D. L., J. A. Barbosa, and P. Calabresi. 1979. $N, N$-dimethylformamide-induced alteration of cell culture characteristics and loss of tumorigenicity in cultured human colon carcinoma cells. Cancer Res. 39:1020-1025.

30. Ryder, K., L. F. Lau, and D. Nathans. 1988. A gene activated by growth factors is related to the oncogene v-jun. Proc. Natl. Acad. Sci. USA. 85:1487-1491.

31. Brinckerhoff, C. E., I. M. Plucinska, L. A. Sheldon, and G. T. O'Connor. 1986. Half-life of synovial cell collagenase mRNA is modulated by phorbol myristate acetate but not by all-trans-retinoic acid or dexamethasone. Biochemistry. 25:6378-6384.

32. Schönthal, A., P. Herrlich, H. J. Rahmsdorf, and H. Ponta. 1988. Requirement for fos gene expression in the transcriptional activation of collagenase by other oncogenes and phorbol esters. Cell. $54: 325-334$.

33. Angel, P., K. Hattori, T. Smeal, and M. Karin. 1988. The jun proto-oncogene is positively autoregulated by its product, Jun/AP-1. Cell. 55:875-885.

34. Piette, J., S.-I. Hirai, and M. Yaniv. 1988. Constitutive synthesis of activator protein 1 transcription factor after viral transformation of mouse fibroblasts. Proc. Natl. Acad. Sci. USA. 85:3401-3405.

35. Matrisian, L. M., P. Leroy, C. Ruhlmann, M.-C. Gesnel, and R. Breathnach. 1986. Isolation of the oncogene and epidermal growth factor-induced transin gene: complex control in rat fibroblasts. $\mathrm{Mol}$. Cell. Biol. 6:1679-1686.

36. Whitham, S. E., G. Murphy, P. Angel, H. J. Rahmsdorf, B. J. Smith, A. Lyons, T. J. R. Harris, J. J. Reynolds, P. Herrlich, and A. J. P. Docherty. 1986. Comparison of human stromelysin and collagenase by cloning and sequence analysis. Biochem. J. 240:913-916.

37. Muller, D., B. Quantin, M.-C. Gesnel, R. Millon-Collard, J. Abecassis, and R. Breathnach. 1988. The collagenase gene family in humans consists of at least four members. Biochem. J. 253:187-192.

38. Quantin, B., and R. Breathnach. 1988. Epidermal growth factor stimulates transcription of the c-jun proto-oncogene in rat fibroblasts. Nature (Lond.). 334:538-539.

39. Chua, C. C., D. E. Geiman, G. H. Keller, and R. L. Ladda. 1985. Induction of collagenase secretion in human fibroblast cultures by growth promoting factors. J. Biol. Chem. 260:5213-5216.

40. Lapierre, L. A., W. Fiers, and J.S. Pober. 1988. Three distinct classes of regulatory cytokines control endothelial cell MHC antigen expression. Interactions with immune $\gamma$ interferon differentiate the effects of tumor necrosis factor and lymphotoxin from those of leukocyte $\alpha$ and fibroblasts $\beta$ interferons. J. Exp. Med. 167:794-804.

41. Collins, T., L. A. Lapierre, W. Fiers, J. L. Strominger, and J. S. Pober. 1986. Recombinant human tumor necrosis factor increases mRNA levels and surface expression of HLA-A,B antigens in vascular endothelial cells and dermal fibroblasts in vitro. Proc. Natl. Acad. Sci. USA. 83:446-450. 